\title{
POWTARZALNOŚĆ NUDY W OPOWIADANIU KONIEC JERZEGO ANDRZEJEWSKIEGO
}

Lukasz Wróblewski

Uniwersytet Jagielloński

\section{/// Repetycja nudy ${ }^{1}$}

W swoim tekście L'ennui: ułamek historii Michał Paweł Markowski wskazuje na wielorakie uwarunkowania nudy, która nigdy nie istnieje samodzielnie. Stwierdza on, że „nie można powiedzieć, czym nuda jest sama w sobie w oderwaniu od kontekstu, w którym się pojawia, w oderwaniu od interpretacji, której jest stawką, a więc także - i przede wszystkim w oderwaniu od języka, w którym zostaje wypowiedziana, i historii, w której zajęła miejsce” (1999: 290-291). Według Markowskiego „nuda jest tym, co o niej mówimy, a nie tym, co bytuje poza zmienną siatką naszych dyskursów" (1999: 291). Majacc na względzie konstruktywistyczne ujęcie nudy zaproponowane przez autora Anatomii ciekawości, zamierzam uczynić przedmiotem mojego artykułu reprezentację nudy zawartą w opowiadaniu Koniec Jerzego Andrzejewskiego.

Jak zauważa Anna Synoradzka-Demadre, „wśród wczesnych opowiadań Andrzejewskiego są utwory osnute wokół kryzysu ekonomicznego, dotykającego ludzi z różnych warstw społecznych” (1997: 19). Chociaż Koniec jest niewatpliwie świadectwem ekonomicznej zapaści charakterystycznej dla rzeczywistości lat 30. XX wieku, daje nam również wgląd w mechanizmy warunkujące nudę. Jej ofiarą pada Gielbard - główny bohater utworu. Analizując opowiadanie Andrzejewskiego, spróbuję zrekonstruować splot czynników generujących nudę. Skupię się zarówno na trudnej sytuacji ekonomicznej, w jakiej znajduje się mężczyzna, jak i na jego relacjach rodzin-

1 Dziękuję Panu Mariuszowi Finkielszteinowi za cenne uwagi, które pozwoliły mi przemyśleć i dopracować podjęte w artykule kwestie dotyczące nudy. 
nych oraz przeżyciach emocjonalnych. Przeanalizuję także związek nudy z rutyną oraz zwrócę uwagę na jej poznawczy aspekt. W ten sposób dokonam wieloaspektowego opisu kategorii problematyzowanej w dziele.

W Pograniczu powieści Kazimierz Wyka łączył pisarstwo Andrzejewskiego z postawą tragiczna. Nie chodziło mu bynajmniej o tragizm jako kategorię estetyczna, lecz o tragiczność rozumiana jako „pewna aura psychiczna, szukanie konfliktów i rozwiązań o pozorach równie nieuniknionych co w tragizmie" (1974: 10). Symptomatyczna dla pisarstwa Andrzejewskiego tragiczność daje się wyraźnie odczuć w opowiadaniu Koniec, prezentującym swoisty upadek psychiczny głównego bohatera. Niepowodzenia Gielbarda zaczynają się wtedy, gdy mężczyzna popada w długi wraz z końcem korzystnej koniunktury. Z dobrze zarabiającego handlarza zamienia się w sklepikarza z trudem wiążącego koniec z końcem. Bohater nie ma pieniędzy na opłacenie rachunków, pracowników czy ubrania. Jest stałym bywalcem lombardu, w którym zastawia swój zegarek. Mimo że pracuje po szesnaście godzin dziennie, nie może żyć godziwie. Cały czas trwa w niepokoju, że przyjdzie do niego komornik, aby wyegzekwować należności. Mężczyzna nie potrafi de facto rozwiązać swoich problemów i nikt nie przychodzi mu z pomoca.

Tym, co trzyma bohatera w owym błędnym kole, jest nuda. Z jednej strony, pozwala mu ona oswajać nieprzychylną codzienność, z drugiej, pogrąża go w niedziałaniu. Zamiast podjać próbę odmiany swojego losu, bohater dzień w dzień angażuje się w rutynowe czynności będące źródłem jego życiowych niepowodzeń. Nuda przejawia się więc przede wszystkim w ciagu repetycji. Jak pisze Marek Zaleski:

O ile zatem trudno powiedzieć, czym jest nuda, o tyle panuje zgoda co do tego, że nuda jest przede wszystkim wynikiem powtórzeń i dopada nas wtedy, gdy udziałem naszym staje się stale «to samo». Jeśli nuda ma do nas tak łatwy przystęp, to dlatego że nasze życie jest pełne powtórzeń i że jego istota jest właśnie powtórzenie. W dzień powszedni i w święta wykonujemy szereg zrutynizowanych czynności. Życie wypełniaja rytuały i ceremonie, w trakcie których wypowiadamy te same słowa i wykonujemy te same gesty. Nasza pamięć odnawia się dzięki powtarzaniu tego, co zostało przez nas zobaczone, usłyszane, doświadczone (1999: 50-51).

Søren Kierkegaard pyta z kolei „,[...] czym byłoby życie, gdyby nie było powtórzenia? Kto chciałby być tablica, na której czas co chwila pisze inne

\section{/ 188 STANRZECZY 2[11]/2016}


słowa, lub nagrobkiem przeszłości? Kto chciałby podlegać temu, co się nieustannie zmienia, co jest nowe i co wciąż od nowa bałamuci duszę?” (2000: 19), wskazując tym samym na niebagatelną wagę powtórzenia w określaniu sensu ludzkiego życia. Choć powtórzenie staje się gwarantem egzystencjalnego ładu, może również pogłębiać monotonię, odbierając życiu sens. Powtórzenie wiąże się wszak z przewidywalnością, którą Peter Toohey uznaje za czynnik kluczowy w doświadczeniu nudy. Autor Historii nudy rozpatruje ją w kategorii emocji, „która rodzi poczucie ograniczenia lub osaczenia ze względu na niedające się uniknąć i obrzydliwie przewidywalne warunki, efektem czego staje się poczucie wyizolowania od otoczenia i od zwykłego rytmu czasu" (2012: 43). Jako taka zdaje się mieć nuda destruktywny wpływ na życie stykającego się z nią podmiotu, redukując je do serii rutynowych czynności.

W tym artykule chciałbym pokazać, w jaki sposób powtórzenie generuje nudę, która doprowadza do kryzysu bohatera. Udowodnię także, że sama świadomość powtórzenia, jaką osiąga bohater, wskazuje na kognitywny wymiar nudy. Dzięki niej Gielbardowi udaje się dostrzec mechanizm kierujący jego życiem i prowadzący go do impasu. „Nuda, choć uciążliwa, może być dobrodziejstwem - swoistym drogowskazem prowadzącym nas do Sensu [...]", stwierdza Maciej Karpiński (2014: 5). Émile Cioran pisze z kolei, że „nudząc się, postrzegamy nieporównanie więcej niż pracując, albowiem wysitek jest śmiertelnym wrogiem medytacji” (2006: 75). Natomiast zdaniem Jacka Barbaleta nuda jest „niespokojnym i drażliwym uczuciem, które zapoczątkowuje proces prowadzący do ciekawości, inwencji i pokrewnych aktywności, w których poszukiwana jest nie tylko różnorodność i nowość, lecz także sens w działaniu" (1999: 641, tłum. L.W.).

Choć nuda w przypadku Gielbarda wiąże się z autopoznaniem, samo odkrycie mechanizmu zawiadującego jego życiem nie pozwala mu na przekroczenie egzystencjalnej monotonii. Ze świadomością nie idzie bowiem w parze gotowość do działania. Gielbard nie wierzy w swoje możliwości sprawcze i jest przekonany, że wyzwolenie z bezwładu musi przyjść z zewnątrz.

\section{/// Świadectwo myśli - świadectwo nudy}

Opowiadanie rozpoczyna opis rutynowej sytuacji, która wskutek nieoczekiwanych okoliczności ulega zakłóceniu. Do sklepu Gielbarda przyjeżdża jak zwykle Konstanty Owczak z towarem. Mężczyzna powinien więc przerwać sprawdzanie rachunków, wezwać krzątającą się w piwnicy 
Władkę i zapewne wyjść mu naprzeciw. Tak się jednak nie dzieje. Bohater bowiem „ledwie uchwycił własny głos, a brzęk łańcuchów stał się naraz niezrozumiale bliski i natarczywy - stwierdził, że coś jest nie w porządku. Stał wśród ciężkich ciemności, pochylony nad piwnica, której nie widział, i z trudem oddychał [...]" (Andrzejewski 1967: 8). Gielbard, jak się dalej okazuje, zasłabł. Mimo to rutynowa czynność odnawia się niejako w jego pamięci. Narrator relacjonuje bowiem myśli mężczyzny, którego martwi zachwianie rutyny: „,[...] Owczakowi nie można kazać czekać za długo, to oczywiste, tylko po co on tak gwałtownie szarpie tymi łańcuchami [...], a Władka też by się mogła odezwać, nie zasnęła chyba w piwnicy?” (tamże: 8) - mówi Gielbard.

Chwilowa niemoc mężczyzny, doprowadzająca do zachwiania generującego nudę mechanizmu, okazuje się paradoksalnie uwierzytelnieniem nudy. Bohater powtarza wszak w pamięci to, czego nie udaje mu się powtórzyć w rzeczywistości, wskutek doznanej niemocy. Mało tego, rozgrywająca się na płaszczyźnie psychicznej repetycja ulega wzbogaceniu o aspekt emocjonalny. Gielbard czuje wściekłość, ponieważ ma świadomość, że to, co trzeba wykonać, a więc sieć nudnych powinności, nie dochodzi do skutku. Ogarniaja go bezsilność i zagubienie, z których stopniowo wyrywaja go obrazy nieśmiało pojawiające się w jego pamięci. Obrazy te odsyłają do tego, co powtarzalne, co stanowi rdzeń nudy. Jednak sam proces myślenia o tym, co jest niezbędne do zaistnienia nudy, osłabia ja. Wszak podczas myślenia bohater nie jest w stanie się nudzić. W myśleniu udaje mu się przekroczyć nudę. Dzięki temu może bowiem wejrzeć w sytuacje, które warunkuja monotonię. Jak zauważa Martin Heidegger, „ostatecznie tylko poza nudą możemy zrozumieć, jak to, co nudne, tkwi w czyjejś nudzie, a nie odwrotnie" (1995: 83, tłum. Ł.W.). Myślenie bohatera ukierunkowuje się na wyszukiwanie czynników wzmagających monotonię. Myślenie to umożliwia więc rozpracowanie struktury nudy, a także jej antropologiczną analizę. Niewątpliwie trudno badać nudę, będąc uwikłanym w codzienne, rutynowe sytuacje. Dopiero autorefleksja, która, co ciekawe, dokonuje się tu w półśnie, zasłabnięciu, bliżej nieokreślonym procesie fizycznej niemocy, pozwala zrozumieć warunkujące ją procesy.

$\mathrm{Na}$ podstawie interpretacji myśli i przeżyć postaci można stwierdzić, że nudę konstytuuje powtórzenie. Nie chodzi tu jednak wyłącznie o przymus spełniania tych samych obowiązków. Powtórzenie jest źródłem nudy o tyle, o ile odbiera podmiotowi dostęp do przeżywania tego, co nie jest mu dane na co dzień. Richard Winter wyróżnia dwa rodzaje nudy. Pierwszy z nich to nuda chwilowa, która wiąże się z koniecznością wykonywania

\section{/ 190 STANRZECZY 2[11]/2016}


pracy, sprowadzającej się do powtarzania tych samych czynności. Drugi rodzaj nudy, to nuda długotrwała, ,[...] o bardziej stałym charakterze, kiedy to nie ma się do zrobienia nic, co się lubi” (2012: 33). Według Wintera „ten drugi, głębszy rodzaj nudy charakteryzuje się utrata pasji życia i brakiem zaangażowania w jakiekolwiek sensowne i dające satysfakcję działanie, przy jednoczesnej tęsknocie za czymś więcej” (tamże: 35). Powtarzające się w życiu bohatera elementy konstytuują ten drugi typ nudy. W tym miejscu spróbuję wskazać na to, co powtarza się w życiu Gielbarda i co tym samym przyczynia się do zaistnienia nudy, blokującej dostęp do tego, czego bohater pragnie najbardziej, a więc do wolności.

\section{/// W pułapce powtórzeń}

W życiu Gielbarda powtarzają się sytuacje, ale również uczucia, sposób komunikowania się z innymi ludźmi, widoki czy wreszcie wspomnienia. Współtworzą one nie tylko przestrzeń nudy, lecz także tożsamość samego bohatera. Brak tych elementów wywołuje w Gielbardzie irytację, zagubienie oraz poczucie zagrożenia ${ }^{2}$. Sprawia, że bohater traci punkty oparcia. Jako taka nuda staje się niezbędnym elementem bycia sobą i bycia u siebie - warunkiem poczucia bezpieczeństwa i zakotwiczenia we własnej tożsamości. Odgłos nadjeżdżającego pociągu czy też widok szafki na łóżku sprawiaja, że bohater wie, gdzie się znajduje i co robił w minione dni.

Gdy Gielbard spogląda na szafkę i nie widzi na niej zegarka, przypomina sobie swoją wizytę w lombardzie i rozmowę z taksatorem, który zaoferował mu małą kwotę za przedmiot, za który wcześniej płacił więcej. Zarówno nadjeżdżający pociag, jak i wizyty w lombardzie stanowia nieodłączny składnik życia mężczyzny. Takich elementów określających horyzont codzienności bohatera pojawia się więcej. Zdarzenia te nadaja jego życiu monotonny charakter i odbierają mu radość. W swoich rozważaniach poświęconych nudzie Heidegger zauważa, że przez pojęcie nudny „rozumiemy «żmudny», «monotonny»; to nie stymuluje i nie ekscytuje, to niczego nie daje, nie ma nam nic do powiedzenia, nie interesuje nas w żaden sposób" (1995: 84, tłum. L.W.). Choć takie ujęcie nudy nie jest pełne i stanowi dla filozofa krok w stronę pogłębionej i kontekstowej analizy omawianej kategorii, doskonale opisuje sytuację Gielbarda. Ten odczuwa brak satysfakcji z powodu konieczności uczestniczenia w powtarzających się sytuacjach. Przymus ciagłego negocjowania z taksatorem przysparza

${ }^{2}$ Zdaniem Barbaleta „nuda jest niepokojem o brak znaczenia w osobistych działaniach albo okolicznościach" (1999: 641, tłum. Ł.W.). 
mu z kolei upokorzenia. Zachowanie pracownika lombardu sprawia, że Gielbard czuje się zdruzgotany i oburzony, co owocuje utratą poczucia rzeczywistości. Widzi taksatora jak przez mgłę oraz godzi się oddać zegarek za niską cenę, ponieważ nie ma innego wyjścia. Tym, co wyznacza zasięg jego myślenia, jest widmo zamknięcia licznika. To ono wzmaga w bohaterze uczucie niepokoju. Mało tego, wyobrażenie taksatora jest czymś natrętnym i uniemożliwia mu normalne funkcjonowanie: „Do żywego poruszyło go wspomnienie dnia, kiedy to od samego rana do późnego popołudnia machinalnie załatwiał klientów pochłonięty nieustanną obawą, że każdej chwili może się zjawić urzędnik z gazowni i zamknąć licznik" (1967: 13).

Problemem dla bohatera okazuje się także powtarzalność afektów, przeżyć czy doświadczeń. Jak wskazuje John Leavitt, „wiele z tego, co na Zachodzie i w innych miejscach identyfikujemy jako doświadczenie emocjonalne, choć doznawane przez indywidualne podmioty, okazuje się stereotypowe w swej naturze, związane - jak utrzymywali konstruktywiści - z powtarzającymi się sytuacjami społecznymi i wspólnymi definicjami” (Leavitt 2012: 83). W efekcie dominujące w życiu Gielbarda uczucia i nastroje są pochodną relacji, w jakich ten rutynowo uczestniczy. Niezdolność przeciwstawienia się żonie i towarzysząca temu frustracja czy chłodne relacje z synem kształtują niewątpliwie emocjonalny kręgosłup bohatera.

Obok uczucia obawy dojmującą emocją, z którą zmaga się mężczyzna, jest gorycz. Znaczeniowo gorycz byłaby tu najbliższa uczuciu rozczarowania i zawiedzenia. Bohater wielokrotnie doświadcza uczucia goryczy i jest ono wywoływane zachowaniem żony Gielbarda, Emilii. Choć małżonkowie żyją ze sobą, są dla siebie całkowicie obcy. Emilia jest zapatrzona w siebie i ignoruje problemy męża. Ich pożycie jawi się jako nudne. Bohaterowie niewiele ze sobą rozmawiają ${ }^{3}$. Fakt, że Gielbard spędza całe dnie w pracy, rzutuje na ich komunikację, która ogranicza się do wymiany kilku słów po powrocie mężczyzny ze sklepu.

Mimo że Emilia prowadzi ustabilizowane życie, czuje się kobietą pokrzywdzona. Nieustannie narzeka na nadmiar pracy czy pogodę oraz neguje zachowanie męża. Co ciekawe, nosi w sobie przeświadczenie, że życie Gielbarda jest znacznie ciekawsze niż jej, ponieważ spędza je poza domem i ma możliwość kontaktowania się z rozmaitymi klientami. To właśnie egoizm Emilii zdaje się głównym źródłem goryczy bohatera. Gielbard czuje,

\footnotetext{
${ }^{3}$ „Gdy przyjeżdżał z Warszawy o północy, Emilia budziła się, zamieniali z sobą kilka słów o zdarzeniach minionego dnia i - oboje znużeni - równocześnie prawie zasypiali” - komentuje narrator (Andrzejewski 1967: 17).
} 
że jest na przegranej pozycji w relacji z żoną. Nie podejmuje z nią nawet prób rozmowy, bo z góry wie, jak ta rozmowa się skończy.

Mówiła, że on niech robi, jak chce - chce spać, więc niech śpi, ale jeśli o nią chodzi, to ona absolutnie nie może tak wcześnie iść spać, do czegoż to podobne o dziewiątej w łóźkach, kości zabolą od leżenia [...]. A od harowania dzień w dzień po siedemnaści godzin to nie mogą zaboleć? Już otworzył usta, żeby to powiedzieć, lecz zatrzymał się w porę. Po co mówić takie rzeczy? W jakim celu? Z góry wiedział, co usłyszy (Andrzejewski 1967: 13-14).

Bohaterowie Końca są skoncentrowani na swoich własnych losach i nie potrafią otworzyć się na relację z drugim człowiekiem. Anna SynoradzkaDemadre, odnosząc się do postaci ze zbioru Drogi nieuniknione, uznała, że protagoniści Andrzejewskiego „patrzą na drugiego człowieka i na własne ciało jak na obce, budzące wstręt przedmioty" (1997: 20). Atrofia więzi międzyludzkich wyeksponowana w Końcu i symptomatyczna dla pozostałych opowiadań z tomu staje się nieodłącznym składnikiem nudy. Rozmowa nie wchodzi w skład repertuaru codziennych zachowań. Małżonkowie nie dialoguja ze sobą w ogóle lub rozmawiają na błahe tematy. W efekcie oddalają się od siebie i zapominaja, jak silna więź ich niegdyś łączyła.

\section{/// Nuda samotności}

Nuda doskwierająca mężowi Emilii jest stanem doświadczanym w samotności. Samotność eskaluje nudę i wprawia podmiot w melancholijny nastrój. Uświadamia mu zarówno klęskę, jakiej doświadcza, jak i znikomość szans na poprawę. Antoni Kępiński zauważa, że „brak perspektyw przyszłości sprawia, że człowiek staje wobec pustki. Nic już w życiu go nie czeka, nic nowego się nie zdarzy, niczego już się nie dokona, życie dopełniło się - consumatum est" (2014: 21). Gielbard, zamiast cieszyć się codziennością, zaczyna zwracać się ku temu, co traci. Zdaniem Julii Kristevy „dla bytu mówiącego życie jest życiem, gdy ma sens: życie stanowi wręcz apogeum sensu. Tracąc sens życia, traci on życie: gdy sens się rozpada, życie jest w niebezpieczeństwie" (2007: 58). Gielbard to świadek upadku własnego życia, które znalazło się na skraju bezsensu. Bohater uświadamia sobie, że jest nic nieznaczącym obiektem dla swoich najbliższych. Co gorsza, ludzie ci, mimo że zaczynaja jawić mu się jako obcy, stają się źródłem jego 
zniewolenia. Owładnięty samotnością i niemocą mężczyzna w serii pytań retorycznych daje dobitnie wyraz doświadczeniu życiowej klęski:

Czy to się doprawdy nigdy, nigdy nie skończy? Czyż nie ma już dla niego, spętanego bezsilnością, rzuconego na przepadłe jak zmięty łach, innego miejsca na świecie prócz tego tutaj? Czy nie ma już prawa do oddychania innym, świeżym powietrzem, do przebywania wśród innych ludzi, do życia takiego, jakim żyją inni ludzie? Och, przestać nareszcie wegetować, skończyć z krecim pełzaniem, raz nareszcie zakosztować pełnej wolności! Niechby przyszła taka chwila, niechby go ze sobą porwała i niechby się działo z nim cokolwiek bądź, byleby tylko zrzucić ze siebie to obecne chomąto, to jarzmo przeklęte i obmierzłe... (Andrzejewski 1967: 25-26).

Gielbard usiłuje reanimować sens swojego życia i z utęsknieniem myśli o czasach minionych. Otaczająca go rzeczywistość mimowolnie wywołuje w jego pamięci obrazy przeszłości. Bohater nie może pogodzić się z tym, że kiedyś świetnie prosperował finansowo, a teraz tonie w długach. Nie jest też w stanie zaakceptować przepaści, która oddziela go od rodziny. Ponieważ nie potrafi dojść do ładu z napierająca na niego teraźniejszością, linearność jego myślenia ulega rozbiciu, a poszczególne porządki czasowe zaczynają się ze sobą przeplatać.

Według Zaleskiego „nuda wtrąca nas w poczucie czasu, w którym zdaje się on nie mieć żadnych specyfikacji: nudząc się, przestajemy rozróżniać przeszłość, teraźniejszość i przyszłość. Wszystko staje się dla nas teraźniejszością bez końca, wieczną teraźniejszością, która zamienia się w martwą, pustą wieczność" (1999: 64). Nuda ,jest oknem na nieskończoność czasu, to znaczy na naszą w nim znikomość”, pisze z kolei Josif Brodski (1996: 91). Tak ujęta nuda wzmaga w bohaterze stan emocjonalnego i fizjologicznego napięcia. Gielbard doświadcza zjawiska, które określić można nieustannym „przydarzaniem się zdarzeń”. Bombarduja go obrazy ludzi, sytuacji, miejsc, rzeczy określających horyzont jego codzienności. Wśród nich postacią najważniejszą i najbardziej obrzydłą jest bezwzględny komornik żądający spłaty długu.

Choć kłopoty ekonomiczne są głównymi problemami, z jakimi zmaga się bohater, i mogą być nawiązaniem do ciężkiej sytuacji materialnej samego Andrzejewskiego i jego rodziców (zob. Synoradzka-Demadre 1997: 19), trudno uznać je za jedyne źródło nudy. Problemy te są raczej elementem 
w ciagu powtórzeń opisanych w opowiadaniu. Fakt, że Gielbard monstrualizuje je w swoich myślach, nierozerwalnie wiąże się z doświadczanym przez niego uczuciem odosobnienia, którego pochodną stają się skłonności narcystyczne. To właśnie samotność bohatera pozwala mu na eksplozję myśli oscylujących wokół jego codziennych doświadczeń. Jak pisze Cezary Karolczak, „samotność jest przeciwna naturze ludzkiej, a jednak wybiera się ją, aby móc dobrze realizować jedną z aktywności ludzkich - myślenie" (Karolczak 2015). Ciężko jednoznacznie określić, na ile samotność jest kwestia wyboru Gielbarda, a na ile czymś narzuconym. Znaczący jest jednak fakt, że bohater nie rozmawia z bliskimi o doskwierających mu problemach - zakłada bowiem (jak można wnioskować - słusznie), że nie zostanie wysłuchany. W efekcie mężczyzna zwraca się ku samemu sobie niejako dialoguje z własnymi myślami, przeżyciami i uczuciami. Powtarzane w myślach epizody z jego życia stają się desperacką próbą ucieczki przed poczuciem pustki i bezsensu, jakie w sobie nosi.

Bohaterowi nie udaje się przepracować trudnych do zniesienia uczuć. Obsesyjne myślenie o relacjach z rodziną dodatkowo wprawia go w stan wewnętrznego rozdarcia. Nieskutecznym remedium na doświadczany kryzys ma być powtarzanie w myślach tego, czego już doświadczył. Powtarzaniu temu towarzyszy typowe w zachowaniu Gielbarda odwrócenie się od świata, wynikające z postrzegania go jako źródła nudy. Świat zmusza go do robienia tego, na co nie ma ochoty. Narzuca mu prawa, których nie chce respektować. Szesnastogodzinna orka w pracy nie przynosi mu praktycznie żadnych korzyści, co najwyżej straty zdrowotne i emocjonalne.

Odnogą nudy staje się więc przymusowość. Richard Winter pisze, że „silne poczucie niemożliwości ucieczki nasila wrażenie nudy: «Nudzę się, kiedy muszę coś zrobić, chociaż wolałbym zajmować się czymś innym»" (2012: 74). Życie Gielbarda, po tym jak stracił atrakcyjny zarobek, sprowadza się do żmudnej i nieprzynoszącej satysfakcji ani godziwych zarobków pracy. Według Kierkegaarda praca pozwala przezwyciężyć nudę, jeśli dostarcza wykonującemu ją przyjemności i zadowolenia. Zdaniem filozofa „bez pracy życie w końcu staje się nudne. Praca, którą się wykonuje, nie powinna właściwie być pracą w ścisłym znaczeniu tego słowa; powinno się pracować dla własnej przyjemności” (2010: 358). W przypadku Gielbarda mamy do czynienia z odwrotną sytuacją. Praca dla niego to przymus odbierający mu jakąkolwiek radość życia, zmuszający go do negacji tego, co w rzeczywistości pragnąłby robić. Nie dziwi więc, że bohater pogrąża się w świecie własnych myśli, by od niej uciec. Zwracanie się ku sobie stanowi dla mężczyzny namiastkę wolności, moment oddechu, przynoszący mu chwilową ulgę. 


\section{/// Obcość w nudzie}

Powtarzane raz po raz czynności do tego stopnia pochłaniają bohatera, że nie potrafi on funkcjonować poza rolą właściciela sklepu. Demaskuje to czas świąt, które zamiast być okazją do zacieśniania więzów rodzinnych, okazują się potęgować alienację:

Jakoś niezręcznie siedziało mu się ze świadomością, że nie musi się co chwila odrywać do kasy czy do czegoś innego. Nieomal brakowało mu stolików kawiarnianych, również światło padało inaczej i aż dziwnie było, że nie ma tutaj Władki ospale się poruszającej i lepiącej się od brudu. Najbardziej jednak z tego wszystkiego zaskakiwała go cisza świąteczna. Czuł, że właśnie dlatego że jest tak dokoła cicho - tu przy stole powinna się toczyć szczególnie żywa $\mathrm{i}$ interesująca rozmowa. Niestety nic ze swej strony interesującego nie miał ani żonie, ani synowi do zakomunikowania (Andrzejewski, 1967: 20).

Bohater zmaga się z wewnętrznym rozdarciem. To, co wymyka się prawom nudy, mężczyzna koduje jako coś niebezpiecznego. Trwanie w nudzie nie pozwala mu jednak odmienić swojego losu. Sprawia, że jest przykuty do jednej roli - Gielbarda sprzedawcy, który wykonuje prace ponad siły i nie czerpie z tego stosownych zysków. Praca okazuje się w efekcie jedynym (bez)sensem jego istnienia. Do tego stopnia zagarnia życie bohatera, że nie potrafi on funkcjonować poza nią. Przyczynia się ona również do degradacji relacji rodzinnych mężczyzny. Zdaniem Tooheya „kiedy nuda długo się utrzymuje i dotyczy czegoś dla nas ważnego pod względem emocjonalnym, to nas w jakiś sposób rujnuje" (2012: 27). Tak dzieje się w przypadku Gielbarda, który doświadcza pustki, przebywając wśród bliskich. Pustki tej, co ważne, nie ma jak wypełnić w obliczu braku pracy stającej się jedynym credo jego życia.

Choć nuda jest uczuciem nieprzyjemnym, pozwala bohaterowi zrozumieć trudną sytuację, w jakiej się znajduje. Gielbard zdaje sobie sprawę, że zarówno żona, jak i jego syn sa dla niego obcymi osobami. Andrzejewski daje czytelnikowi swego rodzaju antropologię kryzysu rodziny, która, choć traktowana jako fundament jednostkowej tożsamości, okazuje się nad wyraz kruchym projektem. $Z$ jednej strony, momenty znużenia sa momentami zrozumienia rodzinnego fiaska, jakiego doświadcza bohater. $Z$ drugiej strony, to właśnie nuda wzmaga izolację - nie wymiana myśli, ale zasty- 
gnięcie w martwocie staje się symptomatyczne dla odbarwionych z uczuć relacji Gielbarda z rodziną. Jak komentuje narrator, „Gielbard starał się uważnie słuchać syna, coraz bardziej jednak poczynała mu dokuczać świadomość, że jest właściwie przez niego usunięty gdzieś na bok. [...] Jadł świąteczne potrawy wolno i bez smaku, wpatrzony w talerz przed sobą, coraz dokuczliwiej dręczony poczuciem obcości we własnym domu" (Andrzejewski 1967: 21).

Świadomość obcości motywuje bohatera do przełamania komunikacyjnego impasu, w jakim się znalazł. Gdy Gielbard dowiaduje się, że jego syn Heniek chce wcześniej wyjechać, zachęca go, by został w domu. To znaczący moment, w którym bohater dopuszcza do głosu tłumione dotąd uczucia, przede wszystkim tęsknotę za bliskim kontaktem z synem, który stał się dla niego obcym człowiekiem. Gielbard pragnie zaistnieć jako ojciec i tym samym przełamać monopol Emilii na relacje z Heńkiem. Andrzejewski odsłania dramat mężczyzny, któremu nie dane jest zaspokoić ojcowskich uczuć. Pozwala nam wejrzeć w intymne afekty, kierujące bohaterem: „Niechby chociaż przez jedną krótką chwilę mógł się znowu poczuć ojcem! W synu zobaczyć syna. Objać go słuchem, wzrokiem, całym sobą" (tamże: 22) - oto pragnienia pograż̇onego w samotności męża Emilii.

Gielbard nie znajduje zrozumienia u Heńka, ponieważ jego syn za nic ma uczucia ojca. Gielbard jest dla niego ojcem wyłącznie w wymiarze symbolicznym, kimś, kto spełnił swoją rolę i przestał być potrzebny dorosłemu synowi. Heniek zdaje się nie zauważać, że rodzicielskie uczucia nie gasna wraz z jego dorastaniem, a problemy, z którymi boryka się ojciec, jedynie potęgują potrzebę bliskości z synem, bliskości, która dla Gielbarda mogłaby być źródłem ulgi i pocieszenia. Nie zaznawszy jednak zrozumienia ze strony Heńka, mężczyźnie nie pozostaje nic innego jak trwanie w schemacie oziębłych relacji z teoretycznie już tylko bliskimi mu osobami. Rewersem nudy jest więc utracony kontakt $z$ rodziną. Bohater nie potrafi jednak przezwyciężyć poczucia wyobcowania i zaangażować się w relacje z tymi, na których mu najbardziej zależy.

Oddalanie się od Emilii i Heńka strąca Gielbarda w czeluście nudy oraz aktywuje melancholijna naturę jego ,ja”. Melancholia stanowi konsekwencję odosobnienia, na które skazują Gielbarda jego bliscy. W ujęciu Agaty Bielik-Robson melancholia jest „tą postawą egzystencjalną, w której najpełniej wyraża się monotonia istnienia oddanego bez reszty ciężarowi, nuda tożsamości, powagi, głębi, pamięci - wszystkich tych modi egzystencjalnych, które opierają się na wytrwałym i sumiennym, zamkniętym w so- 
bie powtórzeniu" (1999: 26). To właśnie rodzina jest kluczowym aspektem myśli bohatera, czymś, co najbardziej przeżywa i ku czemu się odnosi. Mężczyzna nie potrafi pogodzić się z odosobnieniem, ma bowiem świadomość, że wraz z rodziną traci sens swojego życia:

Poczuł się człowiekiem skończonym, wyprutym z wszelkiej życiowej energii. Była to wstrętna pustka. Właściwie była to śmierć, bo czyż życie nie kończy się wtedy właśnie, kiedy człowiek zaczyna sobie zdawać sprawę, że nie ma ani po co, ani dla kogo żyć? Zastanowiło go, że nigdy do tej pory nie myślał o tych racjach, a kiedy raz pomyślał, to okazało się, że ich nie ma. Może więc nigdy ich nie było? (Andrzejewski 1967: 32).

Fundamentalne w doświadczeniu Gielbarda staje się stłumienie komunikacji. Znaczące jest, że w trakcie całego opowiadania jedyną osobą, która wysłuchuje opowieści o finansowej zapaści bohatera, jest czytelnik. Ani żona Gielbarda, ani tym bardziej syn, nie stanowią kręgu osób, którym bohater mógłby powiedzieć o tym, co go boli. W relacji z bliskimi mężczyzna stosuje strategię przemilczania. Żywi wszak przekonanie, że cokolwiek powie, to i tak będzie to źle odebrane. Doprowadza to do sytuacji paradoksalnej. Mężczyzna boi się rozmawiać z żoną, by nie wejść z nią w konflikt. Gielbard odczuwa nawet lęk przed zbudzeniem Emilii: „Czyżby się obudziła? Ogarnął go lęk, że wybiwszy się ze snu może zacząć rozmawiać. Potoczyłyby się wówczas nowe żale, nowe wyrzuty" (1967: 22).

Komunikacja staje się synonimem niebezpieczeństwa. Można powiedzieć, że prowadzi także do relacyjnego chaosu. Bohaterowie nie sa w stanie poprawnie odczytywać swoich intencji. Co gorsza, nie zależy im zbytnio na podtrzymywaniu ze sobą kontaktu. Ich zachowaniem rządzą nuda rozumiana jako opór przed wszelkimi zmianami i przyzwyczajenie do rutynowych obowiązków.

\section{/// Nuda - między narcyzmem a odosobnieniem. Wnioski}

Brak komunikacji między bohaterami podsyca nudę i wywołuje w Gielbardzie wrażenie nadmiaru czasu. To z kolei sprawia, że mężczyzna zaczyna myśleć o tym, co powtarzalne i destabilizujące jego życie, a więc o zbliżających się terminach płatności. Powtarzalność w jednej sferze generuje więc powtarzalność w innych obszarach życia, szczególnie zaś w sferze afektu. Zbliżające się terminy wzmagaja niepokój, niepokój podsyca

\section{/ 198 STANRZECZY 2[11]/2016}


myślenie o terminie płatności. Kryzys finansowy, przymus ciagłej pracy odbijają się na życiu prywatnym mężczyzny. Rodzą w nim także obsesję szukania winnego zaistniałej sytuacji.

Źródeł problemów rodzinnych i finansowych Gielbarda można upatrywać w powtórzeniu, które uniemożliwia budowanie więzi z drugim człowiekiem. Co więcej, eskaluje ono narcystyczną naturę podmiotu. Jednostka znudzona zwraca się wszak sama do siebie. Nudzi się, bo musi lub chce ograniczać swoją aktywność wyłącznie do pielęgnowania własnej podmiotowości. Znudzenie staje się więc tożsame $\mathrm{z}$ autofilią, $\mathrm{z}$ niemożnością zobaczenia nikogo innego poza samym sobą. Zarówno Henryk, Emilia, jak i Gielbard koncentrują się na własnych problemach. Postacie te nie nawiązują relacji między sobą, a jeśli już próbuja ją nawiązać, to kończy się to fiaskiem. Obcości nie sposób przekroczyć, ponieważ uniemożliwia im ona wyjście poza horyzont własnych myśli i zamyka ich w pułapce narcyzmu. Jak pisze Kępiński, „utrwalenie się postawy narcystycznej (przewaga «biorę» nad «daję») czyni człowieka nieszczęśliwym głównie z tej racji, że staje się on niezdolny do miłości, nie może on wyjść w pełni do świata otaczającego, jego uczucia koncentrują się na własnej osobie” (2014: 121).

Nudę podsyca dodatkowo wdrukowany w relację bohaterów nawyk wzajemnego samooskarżania i obwiniania. Bohater, uświadamiając sobie przepaść między nim a żoną, zaczyna widzieć w niej źródło swoich niepowodzeń. W jednej ze scen wpada nieoczekiwanie we wściekłość i ma ochotę pobić Emilię. Narrator przedstawia stan bohatera następująco: „poderwało go, żeby wstać, podejść i bez jednego słowa wyrżnąć ją, gdzie popadnie, choćby w ten stary, obwisły, do starej klaczy podobny pysk. Podobieństwo twarzy Emilii do klaczy dźgnęło Gielbarda pod samo serce" (Andrzejewski 1967: 27). Emilia jawi się bohaterowi jako ikona nieróbstwa, która pozoruje swoje przepracowanie, ,żeby mieć okazję do nowych wymówek, do nowej gadaniny o robocie domowej, praniu, cerowaniu, sklepiku Dutkiewicza, zimie i tak dalej...” (tamże: 27).

Żonę Gielbarda można uznać za ucieleśnienie nudy. W opowiadaniu pojawia się kilkakrotnie jej obraz w czasie snu. Emilia jest przedstawiona jako pochrapująca kobieta symbolizująca znużenie życiem, bezwładność i wyłączenie z codzienności. Problem Emilii polega na tym, że nie jest ona zaangażowana ani w życie męża, ani w żadne inne aktywności. Trwoni czas na odpoczynek i ciągłe utyskiwanie. Powtarzające się chrapanie i narzekanie określają bieg jej życia. To właśnie patrząc na Emilię, bohater uświadamia sobie bezsensowność swojego istnienia. Zdaje sobie sprawę z bezkresu nudy, która zarządza jego życiem, i pragnie ową nudę przekro- 
czyć. „Czy to się doprawdy nigdy, nigdy nie skończy? Czyż nie ma już dla niego, spętanego bezsilnością, rzuconego na przepadłe jak zmięty łach, innego miejsca na świecie prócz tego tutaj?” - (tamże: 25) pyta siebie, patrząc zarazem na wyrażającą martwotę twarz Emilii.

Przyglądając się swoim relacjom z najbliższymi, bohater odkrywa, że to nuda stanowi zasadę jego życia. Mimo to nie udaje mu się jej przezwyciężyć, ponieważ nie dostrzega winy za zaistniały stan rzeczy w samym sobie. Wygodniej mu obarczać innych odpowiedzialnością za swoje własne życie i jego jakość. W efekcie bohater nieświadomie pielęgnuje nudę, która zdaje się rujnować jego egzystencję. Przez to, że nie dba o relacje ani z żoną, ani z synem, jest sam ze swoimi utrapieniami. Jedyne, co mu pozostaje, to bezwolne oddanie się rytmowi powtórzeńt.

Opowiadanie Koniec okazuje się niezwykle interesującym świadectwem nudy, dającym wgląd w mechanizmy warunkujące ten stan. Pokazuje ono, że nuda jest zależna nie tyle od działającego podmiotu, ile raczej od zdarzeń, w jakie jest on uwikłany i jakie umożliwia (praktycznie nieświadomie) swoim zachowaniem. Tym samym jawi się ona jako coś, czego nie sposób w prosty sposób kontrolować. Taka jej natura wynika najpewniej z jej afektywnego podłoża. Jak wskazuje Katarzyna Bojarska, ,afekty [...] wywołuja czynniki, które sa poza kontrola podmiotu, poza jej/jego świadomością i wolą, ale to one określają samą możliwość naszego przeżywania, podatności na bodźce i możliwość ich przetwarzania” (2013: 13).

Gielbard zmaga się z całą gamą przykrych afektów. Odczuwa między innymi smutek, bezsilność, złość czy nienawiść. Bohater boryka się z nimi wielokrotnie, podlegając mechanizmowi afektywnej repetycji. Powtarzajace się przykre uczucia zestawione z powtarzającymi się zdarzeniami, będącymi źródłem utrapienia, jedynie eskalują nudę i wzmagają impas. Dla bohaterów Andrzejewskiego nie istnieje pozytywna alternatywa - przekroczenie nudy okazuje się niemożliwe, ponieważ wymagałoby przeobrażenia relacji i rzeczywistości, w jakiej się znajduja. Gielbardowi, podobnie jak postaciom pozostałej twórczości Andrzejewskiego, nie starcza odwagi, by odmienić swoje życie. W efekcie bohater wraca do rutyny, z której udało mu się na chwile wywikłać dzięki myśleniu o nudzie.

\footnotetext{
${ }^{4}$ Mechanizm powtórzenia okazuje się nader często wykorzystywany przez Andrzejewskiego. Przykładem są Bramy raju, w których monotonia wędrówki do Ziemi Świętej przeplata się z powtarzalnością seksualnych zbliżeń zachodzącym między Blanką a Aleksym (zob. Wróblewski 2015). Rytm powtórzeń generuje wreszcie sam język powieści - niekończące się zdanie oddaje wymijający linearność porządek - buduje rzeczywistość powtórzonych sytuacji, zbliżeń czy afektów. Rzeczywistość, której namiastkę daje nam już Andrzejewski właśnie w Drogach nieuniknionych.
} 
Bibliografia:

/// Andrzejewski J. 1967. Koniec, [w:] tegoż, Niby gaj i inne opowiadania, Państwowy Instytut Wydawniczy.

/// Barbalet J. 1999. Boredom and Social Meaning, „British Journal of Sociology", nr 4, s. 631-646.

/// Bielik-Robson A. 1999. Melancholia i ekstaza, [w:] Nuda w kulturze, red. P. Czapliński, P. Śliwiński, Dom Wydawniczy „Rebis”, s. 25-49.

/// Bojarska K. 2013. Pocæuć myślenie: afektywne procedury historii i krytyki (dziś), „Teksty Drugie”, nr 6, s. 8-16.

/// Brodski J. 1996. Pochwała nudy, tłum. A. Kołyszko, M. Kłobukowski, Wydawnictwo Znak.

/// Cioran É. 2006. Wyznania i anatemy, tłum. K. Jarosz, Wydawnictwo Zielona Sowa.

/// Heidegger M. 1995. The Fundamental Concepts of Metaphysics: World, Finitude, Solitude, tłum. W. McNeill, N. Walker, Indiana University Press.

/// Karolczak C. 2015. Træy sækice o samotności, http://home.agh.edu.pl/ evermind/trzy.htm; dostęp: 12.07.2015.

/// Karpiński M. 2014. Wola i nuda, Self-Publishing.

/// Kępiński A. 2014. Melancholia, Wydawnictwo Literackie.

/// Kierkegaard S. 2000. Powtórz̧enie. Prz̧edmowy, tłum. B. Świderski, W.A.B.

/// Kierkegaard S. 2010. Albo-albo, tłum. K. Toeplitz, t. 2, Wydawnictwo Naukowe PWN i Agora.

/// Kristeva J. 2007. Czarne stońce. Depresja i melancholia, tłum. M.P. Markowski, R. Ryziński, Universitas.

/// Leavitt J. 2012. Znaczenie i cæucie w antropologii emocji, tłum. A. Kościańska, M. Petryk, [w:] Emocje w kulturze, red. M. Rajtar, J. Straczuk, Wydawnictwa Uniwersytetu Warszawskiego, Narodowe Centrum Kultury, s. 59-99.

/// Markowski M.P. 1999. L'ennui: ułamek historii, [w:] Nuda w kulturze, red. P. Czapliński, P. Śliwiński, Dom Wydawniczy „Rebis”, s. 290-316.

/// Synoradzka-Demadre A. 1997. Andrzejewski, Wydawnictwo Literackie. 
/// Winter R. 2012. Nuda w kulturze rozrywki. Poradnik, tłum. Zbigniew Kasprzyk, Wydawnictwo WAM.

/// Wróblewski L. 2015. Afekt jako instrument, afekt jako cel - o ewolucji afeketów w „Trzech opowieściach” Jerzego Andrzejewskiego, [w:] Jerzy Andrzejewski czytany na nown, red. A. Kasperek, J. Wróbel, Wydawnictwo Uniwersytetu Jagiellońskiego, s. 189-207.

/// Wyka K. 1974. Pograniczépowieści, Spółdzielnia Wydawnicza „Czytelnik”.

/// Zaleski M. 1999. Nuda powtórzeñ?, [w:] Nuda w kulturze, red. P. Czapliński, P. Śliwiński, Dom Wydawniczy „Rebis”, s. 50-66.

\section{/// Abstrakt}

Artykul jest próbą spojrzenia na pochodzace z 1933 roku opowiadanie Koniec Jerzego Andrzejewskiego w kontekście wieloperspektywicznie ujętej nudy. W omawianym tekście nuda przejawia się przede wszystkim w rutynowych czynnościach, jakie wykonuje bohater. Ponieważ mężczyzna musi robić ciagle to samo, doświadcza takich negatywnych afektów jak złość, bezsilność czy nienawiść. Autor argumentuje, że tym, co napędza nudę, jest powtórzenie. Powtarzające się sytuacje, zdarzenia, uczucia zmuszają bohatera do przemyślenia sytuacji, w jakiej się znajduje. Chociaż Gielbard dostrzega swoją życiowa klęskę, nie potrafi odmienić swojego losu i przekroczyć nudy. Doświadczenie nudy determinują bowiem jego trudne relacje rodzinne, jak również sytuacja ekonomiczna, której nie sposób odmienić.

Słowa kluczowe:

Andrzejewski, Koniec, nuda, powtórzenie, obcość

\section{/// Abstract}

This article is an analysis of Jerzy Andrzejewski's short story "The End" (1933) in the context of multiple views of boredom. In Andrzejewski's text, boredom appears above all in the routine activities the protagonist is forced to perform. Because he must continually do the same thing, he experiences negative affects such as anger, helplessness, and hate. The author argues that boredom is an experience stimulated by repetition. Recurring situations, events, and feelings force the hero to think about the circumstances in which he finds himself. Although Gielbard perceives his 
life failure, he is unable to change his fate and overcome his boredom. The experience of boredom determines his difficult family relations, as well as his economic conditions, which he is unable to alter.

Keywords:

Andrzejewski, “The End”, boredom, repetition, unfamiliarity 